UDC 547.057.2/.4.51.7/.8

\title{
REACTION OF CHLOROANHYDRIDES OF CYCLOALKANECARBOXILIC ACIDS WITH SOME ALLYLIC CHLORIDES
}

\author{
V.A. Guseinova, G.A. Zaidova, E.I. Mammadov \\ Azerbaijan Technical University, \\ H. Javid Ave. 25, AZ 1073, Baku, Azerbaijan, e-mail: huseynova.vaqifa@mail.ru
}

Received 08.09.2021

Accepted 23.11.2021

\begin{abstract}
The reactions of electrophilic addition of cycloalkane carboxylic acid chlorides with allyl chlorides were studied. It was found, that depending on the chloride structures, 2- and 2,4-substituted furans, 1-R-3,4dichloro-2-butene-1-ones and 1-R-3,4,4-trichloro-1-butanones were obtained.

Keywords: chloroanhydrides of cycloalkane carboxylic acids; 3-chloroprene; 2-methyl-3-chloropropen; 2,3dichloropropene; 3,3-dichloropropene; 2- and 2,4-substituents furans; 1-R-3,4-dichloro-2-butene-1-ones; 1 -R3,4,4-trichlor-1-butanones.
\end{abstract}

DOI: $10.32737 / 2221-8688-2021-3-179-185$

\section{Introduction}

Five-membered heterocyclic compounds with one or two heteroatoms are often found among natural compounds, and therefore, the development of new simple methods for the synthesis of such structures is one of the important problems of modern organic chemistry [1-3]. 1,4-difunctional compounds, most especially, 1,4-haloketones, were successfully used to construct a five-membered heterocycle with one or two heteroatoms [4-10].

As is known, the electrophilic addition of chloroanhydrides of carboxylic acids to 3-chloro- and 2-methyl-3-chloropropenes in the presence of $\mathrm{AlCl}_{3}$ occurs regiospecifically, various products were obtained in keeping with Markovnikov's rule depending on the structure of carboxylic acids. So, when taking chloroacetic-, chloropropionicand chlorobutyric anhydrides, the mixtures of saturated and unsaturated chloroketones were mainly obtained, but when taking chlorocarboxylic anhydrides which have bulky radicals $\left(\geq \mathrm{C}_{4}\right)$, the main reaction products were 2and 2,4-substituted furan derivatives [7,11].
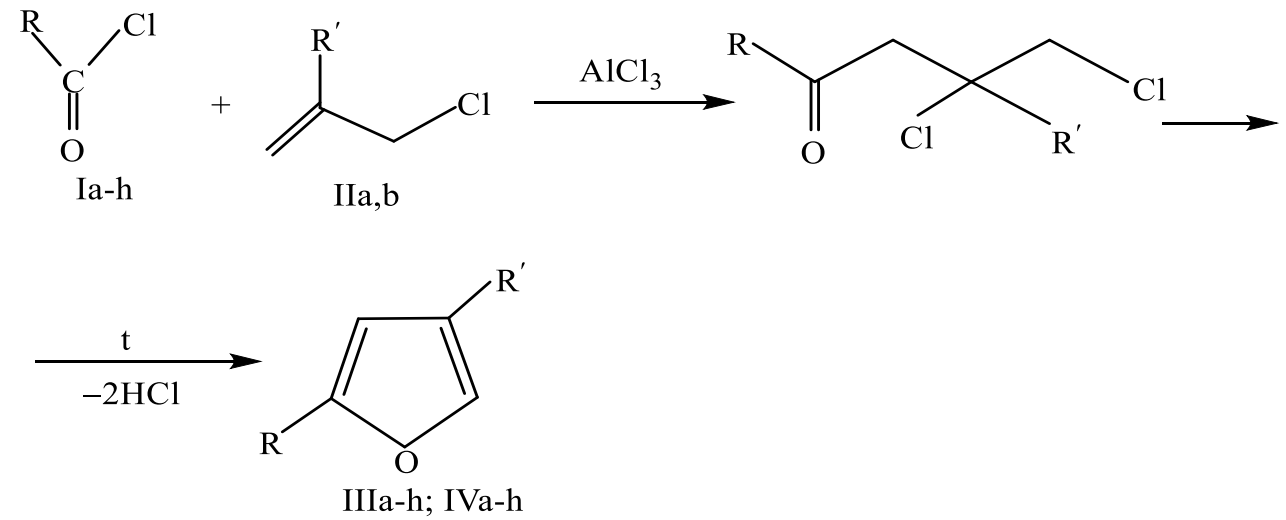

$\mathrm{R}=c-\mathrm{C}_{5} \mathrm{H}_{9}(\mathrm{a}) ; c-\mathrm{C}_{6} \mathrm{H}_{11}$ (b); $1-\mathrm{Cl}-c-\mathrm{C}_{5} \mathrm{H}_{8}$ (c); $1-\mathrm{Cl}-c-\mathrm{C}_{6} \mathrm{H}_{10}$ (d); 4-Cl- $c-\mathrm{C}_{6} \mathrm{H}_{10}$ (e);

$2-\mathrm{Me}-c-\mathrm{C}_{6} \mathrm{H}_{10}(\mathrm{f}) ; 2-\mathrm{Me}-4-\mathrm{Cl}-c-\mathrm{C}_{6} \mathrm{H}_{9}(\mathrm{~g}) ; 1,4-\mathrm{Cl}_{2}-c-\mathrm{C}_{6} \mathrm{H}_{9}(\mathrm{~h})$. 
$\mathrm{R}^{\prime}=\mathrm{H}$ (IIa,IIIa-h); $\mathrm{CH}_{3}$ (IIb, IVa-h).

The structures of furans III and IV have been confirmed by IR and PMR spectroscopic data.

In the Proton MR spectra of compounds III, the signals of the protons of the furan ring appear

in the form of three characteristic multiplets in the

5.72-7.17 ppm region; and in the spectra of furans IV, two protons of the furan ring correspond to two singlet signals in the 5.70-5, 82 and 6.93-7.05 ppm regions (table 1).

Table 1. PMR spectra of furans III, IV

\begin{tabular}{|c|c|c|c|c|}
\hline \multirow[t]{2}{*}{ Compound } & \multicolumn{4}{|c|}{$\delta, \quad$ m.d. } \\
\hline & $\mathrm{R}(\mathrm{H} ; \mathrm{KCCB}, \mathrm{J}, \mathrm{Hz})$ & $\mathrm{R}^{1}$ & $\mathrm{H}^{3}, 1 \mathrm{H}$ & $\mathrm{H}^{5}, 1 \mathrm{H}$ \\
\hline IIIb & $\begin{array}{c}1,08-2,1 \mathrm{~m}(10 \mathrm{H}, \text { cycle }) \\
2,58 \mathrm{~m}(1 \mathrm{H}, \text { cycle })\end{array}$ & $\begin{array}{l}5.98 \mathrm{~m} \\
(1 \mathrm{H})\end{array}$ & $5,72 \mathrm{~m}$ & $7,08 \mathrm{~m}$ \\
\hline IIId & $1,1-2,0 \mathrm{~m}(10 \mathrm{H}$, cycle $)$ & $\begin{array}{l}6.08 \mathrm{~m} \\
(1 \mathrm{H})\end{array}$ & $5,80 \mathrm{~m}$ & $7,10 \mathrm{~m}$ \\
\hline IIIf & $\begin{array}{l}\mathrm{I} \\
0,87 \mathrm{~d}\left(3 \mathrm{H},\left(>\mathrm{C}-\mathrm{CH}_{3}, \mathrm{~J}=6\right) ;\right. \\
1,0-2,2 \mathrm{~m}(10 \mathrm{H}, \text { cycle }) .\end{array}$ & $\begin{array}{l}6.12 \mathrm{~m} \\
(1 \mathrm{H})\end{array}$ & $5,85 \mathrm{~m}$ & $7,15 \mathrm{~m}$ \\
\hline IIIg & $\begin{array}{l}\text { 0,9д }\left(3 \mathrm{H},\left(>\mathrm{I}-\mathrm{CH}_{3}, \mathrm{~J}=6,2\right) ;\right. \\
1,2-2,2 \mathrm{~m}(9 \mathrm{H}, \text { cycle }) ; \\
4,12 \mathrm{~m}(1 \mathrm{H},>\mathrm{CHCl}) .\end{array}$ & $\begin{array}{l}6.15 \mathrm{~m} \\
(1 \mathrm{H})\end{array}$ & $5,87 \mathrm{~m}$ & $7,17 \mathrm{~m}$ \\
\hline $\mathrm{IVb}$ & $\begin{array}{l}\text { 1,1-2,3m (10H, cycle); } \\
2,61 \mathrm{~m}(1 \mathrm{H}, \text { cycle }) .\end{array}$ & $\begin{array}{r}1.94 \mathrm{c} \\
\left(3 \mathrm{H}, \mathrm{CH}_{3}\right) \\
\end{array}$ & $5,74 \mathrm{c}$ & $7,04 \mathrm{c}$ \\
\hline IVe & $\begin{array}{l}\text { 1,2-2,3m (10H, cycle }) ; \\
4,08 \mathrm{~m}(1 \mathrm{H},>\mathrm{CHCl}) .\end{array}$ & $\begin{array}{r}1.98 \mathrm{c} \\
\left(3 \mathrm{H}, \mathrm{CH}_{3}\right) \\
\end{array}$ & $5,70 \mathrm{c}$ & $6,93 \mathrm{c}$ \\
\hline IVf & $\begin{array}{l}\mathrm{I} \\
0,89 \mathrm{~d}\left(3 \mathrm{H},\left(>\mathrm{C}-\mathrm{CH}_{3}, \mathrm{~J}=6\right) ;\right. \\
1,0-2,2 \mathrm{~m}(10 \mathrm{H}, \text { cycle }) .\end{array}$ & $\begin{array}{r}2.0 \mathrm{c} \\
\left(3 \mathrm{H}, \mathrm{CH}_{3}\right)\end{array}$ & 5,78 br.s & $7,02 \mathrm{c}$ \\
\hline $\mathrm{IVg}$ & $\begin{array}{l}\text { 0,85d (3H, }\left(>\mathrm{C}-\mathrm{CH}_{3}, \quad \mathrm{~J}=6\right) ; \\
1,2-2,3 \mathrm{~m}(9 \mathrm{H}, \text { cycle }) ; \\
4,05 \mathrm{~m}(1 \mathrm{H},>\mathrm{CHCl}) .\end{array}$ & $\begin{array}{r}1.98 \mathrm{c} \\
\left(3 \mathrm{H}, \mathrm{CH}_{3}\right)\end{array}$ & $5,82 \mathrm{c}$ & $7,05 \mathrm{c}$ \\
\hline
\end{tabular}

The IR spectra of compounds III, IV have the following absorption bands specific to the furan ring: $\left(\mathrm{cm}^{-1}\right) 3110-3130-\nu_{\mathrm{CH}} ; 1590-1596$ and $1508-1510-v_{\mathrm{C}=\mathrm{C}}, v_{\mathrm{C}=\mathrm{C}} ; 870-890-\boldsymbol{\delta}_{\mathrm{CH}}$.

Dichloroethane and methylene chloride were the most suitable solvents.

The highest yields of furans III,IV were achieved in the following ratio of the initial components I:II: $\mathrm{AlCl}_{3}=1: 1.1: 1.05$.

The reaction temperature significantly depends on the structure of allyl chlorides[9].

We used 2,3-dichloropropene (V) and 3,3dichloropropene (VI) to determine the possibility of heterocyclization of 1,4-chloroketones in fivemembered heterocyclic compounds as allylic chlorides.

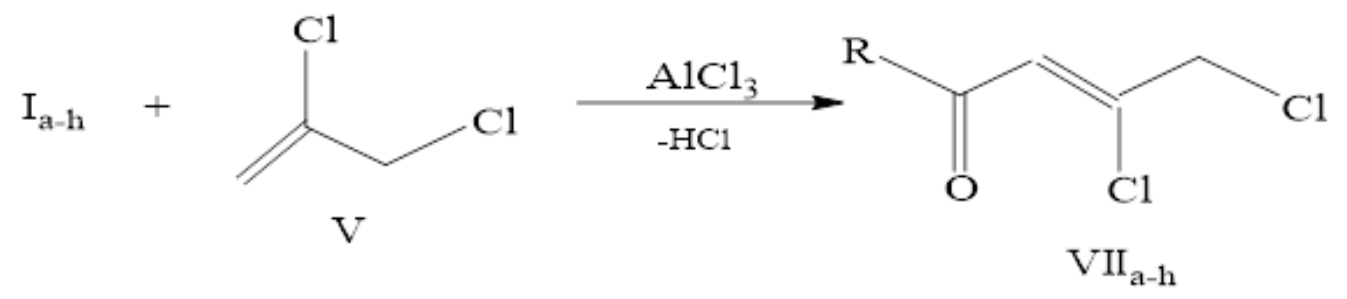

$\mathrm{R}$-above-mentioned radicals 
As compared with chloride IIb, there was a chlorine atom with -J-inductive effect instead of the methyl group in 2,3-dichloropropene. In contrast to chlorides IIa and IIb, the addition of ChA CACA to 2,3-dichloropropene (V) in the presence of $\mathrm{AlCl}_{3}$ occurs at a higher temperature $\left(+20 \div+25^{\circ} \mathrm{C}\right)$, a violent evolution of hydrogen chloride was observed directly during the reaction and 1- R-3,4-dichloro-2-buten-1-ones (VIIa-h) is obtained with $72-83 \%$ yield (table 2 ).

Table 2. Properties of 1-R-3,4-dichloro-2-buten-1-ones (VIIa-h).

\begin{tabular}{|c|c|c|c|c|c|}
\hline Compound & $\mathrm{R}$ & $\begin{array}{c}\mathrm{T}_{\text {boiling, }}{ }^{\circ} \mathrm{C} \\
(\mathrm{mmHg})\end{array}$ & $n_{D}^{20}$ & $d_{4}^{20}$ & $\begin{array}{c}\text { Yield, } \\
\%\end{array}$ \\
\hline VIIa & $c-\mathrm{C}_{5} \mathrm{H}_{9}$ & $108-110(1)$ & 1.5045 & 1.1986 & 76 \\
\hline VIIb & $c-\mathrm{C}_{6} \mathrm{H}_{11}$ & $125-127(1)$ & 1.5065 & 1.1724 & 78 \\
\hline VIIc & $1-\mathrm{Cl}-c-\mathrm{C}_{5} \mathrm{H}_{8}$ & $149-153(4)$ & 1.5205 & 1.3030 & 73 \\
\hline VIId & $1-\mathrm{Cl}-c-\mathrm{C}_{6} \mathrm{H}_{10}$ & $170-174(5)$ & 1.5245 & 1.2877 & 72 \\
\hline VIIe & $4-\mathrm{Cl}-c-\mathrm{C}_{6} \mathrm{H}_{10}$ & $161-163(2)$ & 1.5234 & 12864 & 83 \\
\hline VIIf & $2-\mathrm{Me}-c-\mathrm{C}_{6} \mathrm{H}_{10}$ & $135-138(2)$ & 1.5045 & 1.1671 & 83 \\
\hline VIIg & $2-\mathrm{Me}-4-\mathrm{Cl}-c-\mathrm{C}_{6} \mathrm{H}_{9}$ & $170-173(3)$ & 1.5220 & 1.2805 & 80 \\
\hline VIIh & $1,4-\mathrm{Cl}_{2}-c-\mathrm{C}_{6} \mathrm{H}_{9}$ & $175-182(3)$ & 1.5410 & 1.3886 & 73 \\
\hline
\end{tabular}

The structure of ketones VII was confirmed by IR and PMR spectroscopy (table 3).

Table 3. IR and PMR spectra of compounds VIIb,d-f

\begin{tabular}{|c|c|c|c|c|c|}
\hline \multirow[t]{2}{*}{ Compound } & \multirow[t]{2}{*}{$\mathrm{R}$} & \multicolumn{3}{|c|}{ PMR spectrum, $\delta$, m. d. (KCCB, J, Hz) } & \multirow[t]{2}{*}{ IR spectrum $\left(\mathrm{cm}^{-1}\right)$} \\
\hline & & $\mathrm{R}$ & $\begin{array}{l}-\mathrm{CH}_{2}-\mathrm{Cl}, \\
2 \mathrm{H} \text { br.s }\end{array}$ & $\begin{array}{l}-\mathrm{CH}= \\
1 \mathrm{H}, \mathrm{br} . \mathrm{s}\end{array}$ & \\
\hline VIII & $c-\mathrm{C}_{6} \mathrm{H}_{11}$ & $\begin{array}{l}0.9-2.2 \mathrm{~m}(10 \mathrm{H}, \text { cycle }) \\
2.62 \mathrm{~m}(1 \mathrm{H}, \text { cycle })\end{array}$ & 4.72 & 6.53 & $\begin{array}{c}3118,3075\left(v_{\mathrm{CH}}\right) ; 1730,1705,1684 \\
\left(v_{\mathrm{C}=0)} ; 1618\left(v_{\mathrm{C}=\mathrm{C})}\right.\right.\end{array}$ \\
\hline VIId & $\begin{array}{l}1-\mathrm{Cl}-c- \\
\mathrm{C}_{6} \mathrm{H}_{10}\end{array}$ & $1.0-2.1 \mathrm{~m}(10 \mathrm{H}$, cycle $)$ & 4.74 & 6.60 & $\begin{array}{c}3110,3070\left(v_{\mathrm{CH}}\right) ; 1725,1700,1680 \\
\left(v_{\mathrm{C}=0)} ; 1616\left(v_{\mathrm{C}=\mathrm{C}) .}\right.\right.\end{array}$ \\
\hline VIIIe & $\begin{array}{l}4-\mathrm{Cl}-c- \\
\mathrm{C}_{6} \mathrm{H}_{10}\end{array}$ & $\begin{array}{c}1.2-2.1 \mathrm{~m}(8 \mathrm{H}, \text { cycle }) \\
2.66 \mathrm{~m}(1 \mathrm{H},>\mathrm{CHCl} \text { cycle }) \\
4.04 \mathrm{~m}(1 \mathrm{H},>\mathrm{CHCl} \text { cycle })\end{array}$ & 4.75 & 6.70 & $\begin{array}{c}3110,3080\left(v_{\mathrm{CH}}\right) ; 1734,1702,1691 \\
\left(v_{\mathrm{C}=0}\right) ; 1610\left(v_{\mathrm{C}=\mathrm{C}) .}\right.\end{array}$ \\
\hline VIIf & $\begin{array}{c}2-\mathrm{Me}- \\
c-\mathrm{C}_{6} \mathrm{H}_{10}\end{array}$ & $\begin{array}{c}\mathrm{I} \\
0.88 \mathrm{~d}\left(3 \mathrm{H},\left(>\mathrm{C}-\mathrm{CH}_{3},\right.\right. \\
\mathrm{J}=6) ; 1.1-2.4 \mathrm{~m}(10 \mathrm{H}, \text { cycle })\end{array}$ & 4.64 & 6.60 & $\begin{array}{c}3105,3040\left(v_{\mathrm{CH}}\right) ; 1710,1694,1680 \\
\left(v_{\mathrm{C}=0}\right) ; 1608\left(v_{\mathrm{C}=\mathrm{C})} .\right.\end{array}$ \\
\hline
\end{tabular}

As a continuation of the study, 3,3dichloropropene (VI) was taken. Chloroanhydrides of $\mathrm{Ib}$,e were added to chloride VI according to Markovnikov's rule at a temperature of $-10 \div-15 \mathrm{oC}$ in the presence of
$\mathrm{AlCl} 3$ and the resulting compounds 1-R-3,4,4trichloro-1-butanones (VIIIb,e) turned out to be stable substances: they did not eliminate $\mathrm{HCl}$ and do not cyclize to furan derivatives during distillation. 


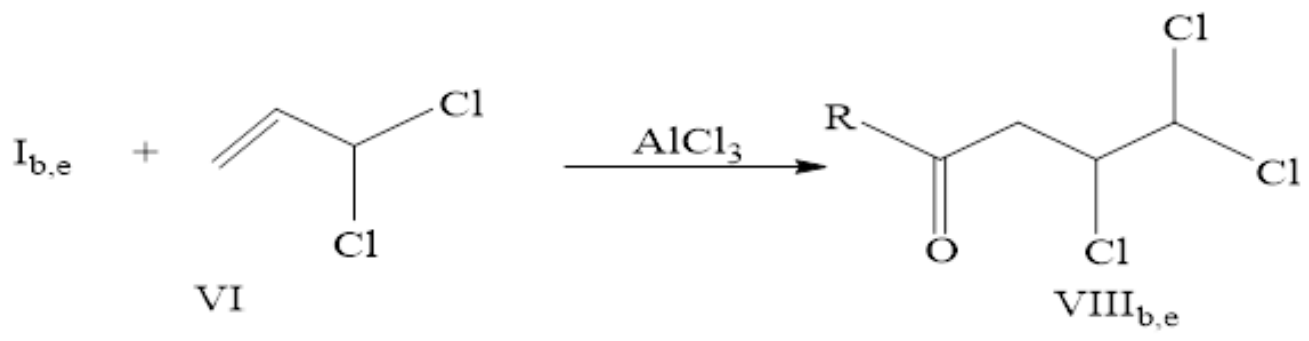

Experimental part

IR and PMR spectra were recorded on a "UR-20" spectrometer in the form of a thin layer and on a Briker AM-360 instrument $(360 \mathrm{MHz})$, respectively, HMDS or TMS was chosen as an internal standard.

1.Obtaining the initial allylic chlorides. 3Chloropropene (IIa) and 2-methyl-3chloropropene (IIb) among initial allylic chlorides were in the form of commercial preparations.

2,3-Dichloropropene (V) has been obtained by dehydrochlorination of 1,2,3-trichloropropane with $\mathrm{KOH}$ in absolute alcohol [11]. Physicochemical constants of dichloride V: tboiling $-93-95^{\circ} \mathrm{C} ; n_{D}^{20}-1.4600 ; d_{4}^{20}-1.2084$, yield $87 \%$.

3,3-dichloropropene(VI) was obtained from acrolein and $\mathrm{PCl}_{5}$ according to the known method illustrated in [12]: $\mathrm{t}$ boiling $-83-84^{\circ} \mathrm{C}, n_{D}^{20}-1.4462$; $d_{4}^{20}-1.1689$.

\section{Synthesis of chloroanhydrides of}

cycloalkanecarboxylic acids

2.1. Obtaining chloroanhydrides Ia,b,e-g. 2.2. Obtaining chloroanhydrides Ic,d,h. The appropriaste 1-chloro-substituted chloroanhydrides of cycloalkanecarboxylic acids (Ic,d,h) were obtained by chlorination of chloroanhydrides Ia,b,e.

The general technique for obtaining chloroanhydrides Ic,d,h. A weighed portion of the chloroanhydride (Ia,b,e) was placed in a specially prepared chlorinator and heated up to a temperature of $60-70^{\circ} \mathrm{C}$. A weak flow of chlorine obtained by the interaction of concentrated hydrochloric acid with $\mathrm{KMnO}_{4}$ was passed through the chlorinator. The flow of chlorine was stopped when the weight of the chlorinator with the content is $5-10 \%$ less than theoretical. After repeated distillation, $\alpha$-chloro-substituted chloroanhydrides Ic, $\mathrm{d}, \mathrm{h}$ have been obtained (table 4).

Table 4. Some characteristics of chloroanhydrides Ia-h.

\begin{tabular}{|c|c|c|c|c|}
\hline Compound & $\begin{array}{c}\mathrm{T}_{\text {boiling }},{ }^{\circ} \mathrm{C} \\
(\mathrm{mmHg})\end{array}$ & $n_{D}^{20}$ & $d_{4}^{20}$ & Yield, \% \\
\hline $\mathrm{Ia}$ & $158-160$ & 1.4650 & 1.1034 & 92 \\
\hline $\mathrm{Ib}$ & $181-183$ & 1.4760 & 1.0945 & 94 \\
\hline $\mathrm{Ic}$ & $75-80(15)$ & 1.4920 & 1.2931 & 76 \\
\hline $\mathrm{Id}$ & $108-112(15)$ & 1.4960 & 1.2527 & 80 \\
\hline $\mathrm{Ie}$ & $105-108(15)$ & 1.4955 & 1.2498 & 90 \\
\hline If & $78-80(15)$ & 1.4766 & 1.0969 & 86 \\
\hline Ig & $138-140(15)$ & 1.5164 & 1.3595 & 88 \\
\hline Ih & $130-135(20)$ & 1.5150 & 1.3860 & 78 \\
\hline
\end{tabular}


3. Acylation of 3-chloro-and 2-methyl-3chloropropenes (IIa,b).

3.1. Synthesis of furans IIIa-h. First $34.7 \mathrm{~g}$ $(0.26 \mathrm{~mol})$ of $\mathrm{AlCl}_{3}$ and then $36.6 \mathrm{~g}(0.25 \mathrm{~mol})$ of chloroanhydride of cyclohexanecarboxylic acid (Ib) were added to $100 \mathrm{ml}$ of dry dichloroethane at $-20^{\circ} \mathrm{C}$. After that, $20.7 \mathrm{~g}(0.27 \mathrm{~mol})$ of $3-$ chloropropene were gently added at a temperature of $-15 \div-20^{\circ} \mathrm{C}$. The reaction mixture was stirred until achieving the room temperature and decomposed with $5 \% \mathrm{HCl}$, the organic layer was separated, and the aqueous layer was extracted with ether $(2 \times 100 \mathrm{~mL})$. The combined organic layers were washed with water, then with $5 \%$ $\mathrm{NaHCO}_{3}$ solution and dried over $\mathrm{CaCl}_{2}$. The solvents were removed, and the residue is distilled in the vacuum, as a result of that 2cyclohexylfuran was obtained (IIIb, table 5). Furans IIIa,c-h were obtained by the analojical method, the characteristics of which are shown in Table 5.

3.2. Synthesis of furans IVa-h. According to the above method, chloroanhydrides Ia-h were condensed with 2-methyl-3-chloropropene (IIb) at a temperature of $-20 \div-25^{\circ} \mathrm{C}$; and 2-cycloalkyl-4methylfurans obtained (IVa-h, Table 5).

Table 5. Some characteristics of furans IIIa-h, IVa-h.

\begin{tabular}{|c|c|c|c|c|}
\hline Compound & $\begin{array}{c}\mathrm{T}_{\text {boiling, }}{ }^{\circ} \mathrm{C} \\
(\mathrm{mmHg})\end{array}$ & $n_{D}^{20}$ & $d_{4}^{20}$ & Yield, \% \\
\hline IIIa & $47-49(5)$ & 1.4860 & 0.9922 & 86 \\
\hline IIIb & $55-58(5)$ & 1.4870 & 0.9908 & 91 \\
\hline IIIc & $88-90(10)$ & 1.4970 & 1.1290 & 56 \\
\hline IIId & $108-110(5)$ & 1.5105 & 1.1328 & 64 \\
\hline IIIe & $102-105(5)$ & 1.5095 & 1.1261 & 68 \\
\hline IIIf & $82-85(5)$ & 1.4825 & 0.9666 & 66 \\
\hline IIIg & $110-112(4)$ & 1.4920 & 1.0507 & 56 \\
\hline IIIh & $119-121(5)$ & 1.5180 & 1.2355 & 55 \\
\hline IVa & $63-65(15)$ & 1.4840 & 0.9812 & 84 \\
\hline IVb & $72-74(15)$ & 1.4855 & 0.9626 & 92 \\
\hline IVc & $102-104(5)$ & 1.4980 & 1.1078 & 62 \\
\hline IVd & $125-127(10)$ & 1.5075 & 1.1098 & 66 \\
\hline IVe & $135-137(25)$ & 1.5060 & 1.1033 & 70 \\
\hline IVf & $90-92(5)$ & 1.4815 & 0.9605 & 67 \\
\hline IVg & $97-99(2)$ & 1.4902 & 1.0582 & 61 \\
\hline IVh & $131-133(3)$ & 1.5165 & 1.2069 & 59 \\
\hline
\end{tabular}

4. Synthesis of 1-R-3,4-dichloro-2-buten1-ones (VIIa-h). $0.1 \mathrm{~mol}$ of chloroanhydride of cycloalkanecarboxylic acid (Ia-h) was added dropwise with stirring to a suspension consisting of $14.7 \mathrm{~g}(0.11 \mathrm{~mol})$ of aluminum chloride and 70 $\mathrm{ml}$ of dichloroethane, cooled down to $-15^{\circ} \mathrm{C}$. Then the temperature was raised up to $+20^{\circ} \mathrm{C}$ and $13.3 \mathrm{~g}(0.12 \mathrm{~mol})$ of 2,3-dichloropropene were added dropwise. In this case, a violent evolution of hydrogen chloride occured. The reaction mixture was stirred for another 0.5 hour at a temperature of $+20 \div 25^{\circ} \mathrm{C}$ until stopping the evolution of hydrogen chloride and poured onto ice acidified with $\mathrm{HCl}$. The organic layer was separated, the aqueous layer extracted with ether $(2 \times 100 \mathrm{ml})$; the combined organic extracts were washed with water, then with $5 \% \mathrm{NaHCO}_{3}$ solution and dried over $\mathrm{CaCl}_{2}$. The solvents were removed, and the residue was distilled to obtain 1-R-3,4-dichloro-2-buten-1-ones (VIIa-h), the 
characteristics and yields of compounds are shown in Table 2.

5. Obtaining of 1-R-3,4,4-trichloro-1butanones (VIIIb,e). The acylation of 3,3dichloropropene with chloroanhydride of cyclohexane- and 4-chlorocyclohexanecarboxylic acids was carried out according to the 3.1 method at a temperature of $-10 \div-15^{\circ} \mathrm{C}$ in the presence of $\mathrm{AlCl}_{3}$ and the trichlorobutanones VIIIb,e were obtained by distillation.

1-Cyclohexyl-3,4.4-trichloro-1-butanone

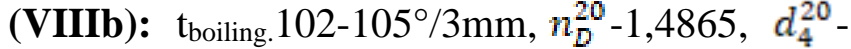
1,2028. IR spectra $\left(\mathrm{cm}^{-1}\right): 1705\left(v_{\mathrm{C}=0}\right) ; 759,686$ $\left(v_{\mathrm{C}-\mathrm{Cl}}\right)$. PMR spectra $(\delta, \mathrm{m}, \mathrm{d}): 0,83-2,0(11 \mathrm{H}, \mathrm{m})$, 2,42 $\left(2 \mathrm{H}, \mathrm{m}, \mathrm{COCH}_{2}\right), 3,67(1 \mathrm{H}, \mathrm{t}, \mathrm{CHCl}), 6.02$ $\left(1 \mathrm{H}, \mathrm{m}, \mathrm{CHCl}_{2}\right)$. Yield is $52 \%$.

1-(4'-Chlorocyclohexyl)-3,4,4-trichloro-1butanone(VIIIe): $\quad t_{\text {boiling. }}$ 118-120/3mm, $n_{D}^{20} 1,5030, \quad d_{4}^{20} 1,3164 . \quad$ IR $\quad \operatorname{spectra}\left(\mathrm{cm}^{-1}\right)$ : $1714\left(v_{\mathrm{c}=0}\right), 751,680\left(v_{\mathrm{C}-\mathrm{Cl}}\right)$. PMR spectra: 1,2$2,2(10 \mathrm{H}, \mathrm{m}), \quad 2,4\left(2 \mathrm{H}, \mathrm{m}, \quad \mathrm{COCH}_{2}\right), \quad 3,59(1 \mathrm{H}, \mathrm{t}$, $\mathrm{CHCl}), 5,97\left(1 \mathrm{H}, \mathrm{m}, \mathrm{CHCl}_{2}\right)$. Yield is $56 \%$.

\section{References}

1. Joule J., Mills K. Chemistry of Heterocyclic Compounds. Moscow: Mir Publ., 2009, 728 p.

2. Yurovskaya M.A. Chemistry of Aromatic Heterocyclic Compounds. Moscow: Binom Publ., 2015, 208 p.

3. Ansari A., Ali A., Asif M. Review: biologically active pyrazole. New J. Chem., 2017, vol. 41, pp.16-41.

4. Ismailov V.M., Ibragimova G.G., Sadikhova N.N. Synthesis of functionally substituted derivatives of furan and resorcinol based on dimethyl 3-oxopentadioate. Zhurnal organicheskoi khimii. 2017, vol. 53, no. 6, pp. 933-935. (In Russian).

5. Kwiesien H., Wodnicka A. Five-Membered Ring Systems: Furans and Benzofurans. Progress in Heterosyslis Chemistry. 2020, no. 31, pp. 281-323.

6. Ismailov A.G., Mamedov E.I. Synthesis of furan derivatives by condensation of cycloalkanecarboxylic acid chlorides with allyl chloride. Zhurnal organicheskoi khimii. 1974, vol.10, no. 5, pp.1129-1130. (In Russian).

7. Ibragimov I.I., Mamedov E.I., Ismayilov A.T., Aliev A.G., Mekhtieva Sh.Z., Jafarov V.G., Belyaeva V.I. Chemistry of allylic type systems. II.Acylation of 3-bromo- and 2methyl-1-propenes. Zhurnal organicheskoi khimii.1990, vol. 26, no. 8, pp.1648-1654. (In Russian).

8. Karayeva A.R. Synthesis and conversion of pyrazole derivatives. Chemical Problems. 2019, no. 4, pp. 584-590.

9. Mammadov E., Mammadov A., Huseynova V., Zaidova Q., Gasimova F. Temperature Dependence of the Reaction of Elektrophilic Addition of Acyl Chlorides to Allyl Chloride. $6^{\text {th }}$ International Conference: Thermophysisal and Mechanical Properties of Advanced Materials (Thermam 2019). Izmir. Turkey. 2224 september 2019, pp. 54-55.

10. Kapaeva A.R., Aliev A.G., Hajili R.A., Mamedov B.A. Synthesis and properties of 3alkyl-1-methoxycarbonyl-5-

dialkylaminomethylpyrazolines and their functional derivatives. Zhurnal organicheskoi khimii. 2018, vol. 88, no. 5, pp. 858-961. (In Russian).

11. Zaidova GA, Mammadov EI, Ismayilova SQ Study of oxidation products of 3-chlorine, 2methyl-3-chlorine and 2,3-dichloropropenes. AzTU. Scientific works. 2019, no. 2, pp. 101-104. (In Azerbaijani).

12. Buhler K., Pearson D. Organic syntheses. Moscow: Mir Publ., 1973, part 1, pp. 379380 . 


\title{
TSIKLOALKANKARBON TURŞULARI XLORANHIDRIDLORININ BOZI ALLIL TIPLI XLORIDLORLO REAKSIYASI
}

\author{
V.Ә. Hüseynova, Z.Ә. Zaidova, E.İ. Mommədov \\ Azarbaycan Texniki Universiteti, \\ AZ 1073 Baki, H.Cavid pr.107; e-mail: huseynova.vaqifa@mail.ru
}

Tsikloalkankarbon turşuları xloranhidridlorin allil tipli xloridlorlo elektrofil birloşmə reaksiyaları tədqiq edilmişdir. Müəyyən olunmuşdur ki, xloridlarin quruluşundan asıll olaraq 2- vo 2,4avazlifuranlar, 1-R-3,4-dixlor-2-buten-1-onlar va 1-R-3,4,4-trixlor-1-butanonlar alınır.

Açar sözlor: tsikloalkankarbon turşularının xloranhidridlari; 3-xlorpropen; 2-metil-3-xlorpropen; 2,3-dixlorpropen; 3,3-dixlorpropen; 2- va 2,4-əvazlifuranlar; 1-R-3,4-dixlor-2-buten-1-onlar; 1-R3,4,4-trixlor-1-butanonlar.

\section{РЕАКЦИЯ ХЛОРАНГИДРИДОВ ЦИКЛОАЛКАНКАРБОНОВЫХ КИСЛОТ С НЕКОТОРЫМИ ХЛОРИДАМИ АЛЛИЛЬНОГО ТИПА}

\author{
В.А. Гусейнова, Г.А. Заидова, Э.И. Мамедов \\ Азербайджанский Технический Университет, \\ AZ1073 Баку, пр. Г. Джавида, 107; e-mail:huseynova.vaqifa@mail.ru
}

Исследовань реакции электрофильного присоединения хлорангидридов циклоалканкарбоновых кислот с хлоридами аллильного типа. Установлено, что в зависимости от структуры хлоридов получаются 2- и 2,4-замещченные фураны, 1-R-3,4-дихлор-2-бутен-1-оны $u$ 1-R-3,4.4трихлор-1-бутаноны.

Ключевые слова: хлорангидриды циклоалканкарбоновых кислот; 3-хлорпропен; 2-метил-3хлорпропен; 2,3-дихлорпропен; 3,3-дихлорпропен; 2- и 2,4-замещенные фураны; 1-R-3,4-дихлор2-бутен-1-оньі; 1-R-3,4,4-трихлор-1-бутаноньл. 